\title{
Macrofungi on the coastal sand dunes of south-western India
}

\author{
Ghate SD, Sridhar KR* and Karun NC \\ Department of Biosciences, Mangalore University, Mangalagangotri, Mangalore 574 199, India
}

Ghate SD, Sridhar KR, Karun NC 2014 - Macrofungi on the coastal sand dunes of south-western India. Mycosphere 5(1), 144-151, Doi 10.5943/mycosphere/5/1/6

\begin{abstract}
This paper documents the distribution and diversity of macrofungi in coastal sand dunes characterized by less, moderate and severe disturbance regimes of the south-western India. Diversity was higher in moderately disturbed dunes compared to less or severely disturbed dunes. Among the 38 macrofungi recovered, ten, six, two and one species were edible, ectomycorrhizal, medicinal and considered to be of decorative value, respectively. Ten macrofungi were dominant ( $\geq 5$ fruit bodies $/ 625 \mathrm{~m}^{2}$ ) on the coastal sand dunes. These were Amanita sp., Collybia dryophila var. extuberans, C. fusipes, Coprinus plicatilis, Dacryopinax spathularia, Lactarius sp., Lentinus squarrosulus, Marasmius kisangensis, Marasmius sp. 2 and Scleroderma citrinum). The coastal sand dunes are under severe anthropogenic pressure, especially urbanization, sand extraction, agricultural activities and seawall construction. The revegetated dunes are mainly represented by exotic tree species (e.g., Acacia and Casuarina), which are often harvested. Due to the removal of native vegetation and the 'grow and harvest' policy associated with exotic trees, the native flora, fauna and macrofungi of the coastal sand dunes are severely threatened. The results obtained in the present pilot study point out the need for long-term temporal and spatial investigation of the macrofungal resource of coastal sand dunes to gain a more comprehensive knowledge on their abundance, diversity, ecological significance, benefits and what must be done to implement strategies necessary for conservation.
\end{abstract}

Key words - dunes - mushrooms - woodrot fungi - disturbance - conservation

\section{Introduction}

Coastal sand dunes (CSD) are the most dynamic and ecologically sensitive transition zones linking terrestrial and marine ecosystems. They are versatile habitats owing to several direct and indirect ecological services, especially the filtration of seawater, recycling of nutrients, prevention of floods and protection against storms (McLachlan \& Brown 2006, Maun 2009). However, the CSD are the most threatened habitats throughout the world and have been transformed considerably due to urbanization, industrialization, deforestation and agricultural activities (Clark 1996, Schlacher et al. 2007, Malavasi et al. 2013). Being highly vulnerable for severe anthropogenic pressures, the ecological services of CSD are hampered mainly due to the loss of biodiversity (EEA Technical Report 2001-2006). Although the landscape restoration and management of CSD has become a daunting task, there is an urgent need to conserve and restore this ecosystem for biodiversity protection and long-term benefits.

One of the major ways in which CSD stabilization can occur is to depend on the vegetation, especially the psammophytes, since they play vital role in building and stabilizing the dunes due to 
their sand-binding and salt-tolerant capabilities (Banerjee et al. 2002, Rodrigues et al. 2011). Apart from vegetation, micro- and macrofungi (saprophytic, mycorrhizal and endophytic fungi) are directly or indirectly responsible for the stability and perpetuation of psammophytes in CSD habitats (Brundrett 1991, Maun 2009, Sridhar 2009). Several reports (Japan, Europe, United States, Brazil and Seychelles) have revealed that macrofungi are inseparable components of CSD (ECCF 2001, Ashkannejhad \& Horton 2005, O’Hanlon \& Harrington 2011, Høiland 2012, Sulzbacher et al. 2013). The macrofungal resource of CSD encompass a variety of ectomycorrhizal fungi (Ashkannejhad \& Horton 2005, Tedersoo et al. 2007, Wolfe et al. 2010, Sulzbacher et al. 2013), agarics (O'Hanlon \& Harrington 2011, Takehashi et al. 2012), new records and new species (Vila et al. 1999, Takehashi et al. 2007, Hoshino et al. 2009, Taiga et al. 2011, Akata \& Yaprak 2013, Sá et al. 2013). In contrast, there seems to be no literature available on the macrofungi of CSD of south-western India, although there are reports on the occurrence of marine, arbuscular mycorrhizal and endophytic fungi (Beena et al. 2000, Prasannarai \& Sridhar 2001, Seena \& Sridhar 2004). Therefore, in an effort to advance conservation, the objectives of the current pilot study were to document and assess the diversity of mushrooms and woodrot fungi prevailing in CSD in southwestern India under different disturbance regimes.

\section{Materials \& Methods}

\section{Study site and vegetation}

As evident throughout the rest of the world, the CSD of south-western India are also facing anthropogenic pressures. Figure 1 shows the past and present status of the CSD in south-western India. The major human interference on these dunes include building roads, residential construction, agricultural development, boat building/fishing, recreation activities and seawall construction (Sridhar 2009). Based on the status of disturbance, three CSD regions were chosen for the macrofungal survey. These were Someshwara $\left(12^{\circ} 47^{\prime} \mathrm{N}, 74^{\circ} 51^{\prime} \mathrm{E}\right)$ consisting of fairly less disturbed dunes, Thannir Bavi $\left(12^{\circ} 53^{\prime} \mathrm{N}, 7^{\circ} 48^{\prime} \mathrm{E}\right)$ encompassing moderately disturbed dunes and Kaup dunes $\left(13^{\circ} 12^{\prime} \mathrm{N}, 74^{\circ} 44^{\prime} \mathrm{E}\right)$ facing severe disturbances. According to the extent of anthropogenic pressure, the natural vegetation is declining and leading to a preponderance of disturbance-tolerant vegetation. The areas of former dune vegetation are now occupied mainly by paddy fields (Oryza sativa) and plantations (e.g. Cocos nucifera). In addition, exotic tree species (e.g. Acacia and Casuarina) have been planted on the dunes to prevent erosion. Table 1 gives existing natural and exotic vegetation (trees, shrubs, herbs, creepers and grasses) in and around the sampling stations. The vegetation pattern differs, with highest diversity in moderately disturbed dunes of Thannir Bavi, followed by less disturbed dunes (Someshwara) and severely disturbed dunes (Kaup).

Table 1 Vegetation in and around the sampling stations of coastal sand dunes on the south-western coast of India surveyed for macrofungi.

\begin{tabular}{ll}
\hline Type of vegetation & Taxon \\
\hline Trees & Acacia auriculiformis, Borassus flabellifer, Casuarina equisetifolia, Cocos nucifera \\
and Erythrina variegata \\
Calotropis gigantea, Cassia tora, Scaevola plumieri, S. sericea and S. taccada and \\
Sesbania bispinosa \\
Acanthospermum hispidum, Ageratum conyzoides, Alysicarpus rugosus, Borreria \\
articularis, Cassia tora, Chromolaena odorata, Crotalaria retusa, C. verrucosa, \\
Cyanotis cristata, Eclipta alba, Emilia sonchifolia, Evolvulus alsinoides, Hedyotis \\
corymbosa, Launaea sarmentosa, Ludwigia hyssopifolia, Mimosa pudica, Phyla \\
nodiflora, Polycarpaea corymbosa, Sesbania bispinosa, Sesuvium portulacastrum \\
and Tephrosia purpurea \\
Bulbostylis barbata, Canavalia cathartica, C. maritima, Derris trifolorum, \\
Fimbristylis argentea, Ipomoea pes-caprae, Paspalum vaginatum, Panicum \\
repens, Perotis indica, Spinifex littoreus, Tridax procumbens and Wedelia biflora \\
Cyperus arenarius, C. compressus and C. pedunculatus \\
\hline
\end{tabular}




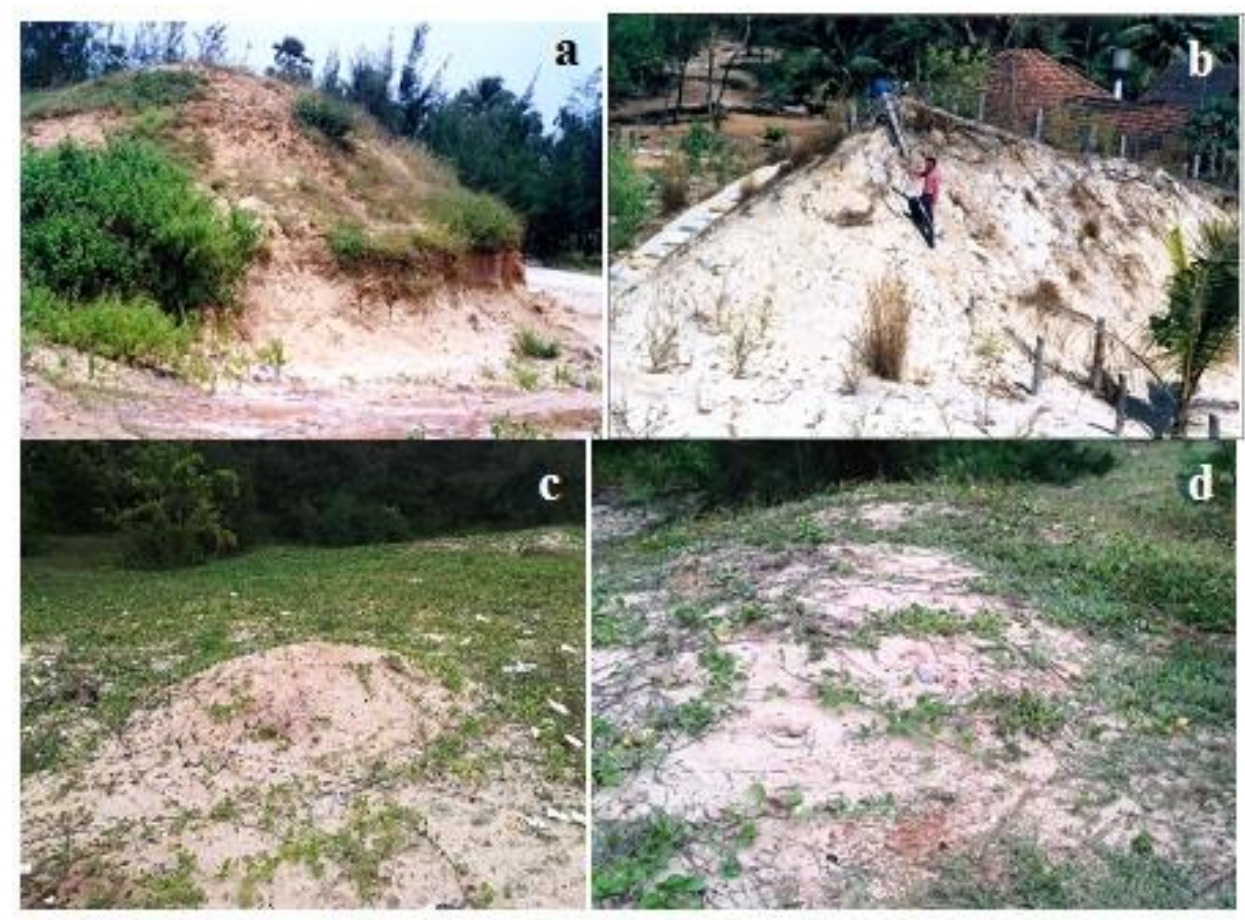

Fig. 1 - a, Remnant of well-established CSD on the beach of Beejadi $\left(13^{\circ} 33^{\prime} \mathrm{N}, 74^{\circ} 40^{\prime} \mathrm{E}\right)$ in southwestern India (note the road construction beside the dune); b, partially excavated CSD near Saligrama $\left(13^{\circ} 30^{\prime} \mathrm{N}, 74^{\circ} 41^{\prime} \mathrm{E}\right.$ ) (note the construction and plantation activities on the dune surroundings); c, and d, recent small dunes at the formation stage on the beach of Thannir Bavi $\left(12^{\circ} 53^{\prime} \mathrm{N}, 74^{\circ} 48^{\prime} \mathrm{E}\right)$, with surrounding creepers also evident.

\section{Survey of macrofungi}

The survey of macrofungi was carried out in the mid- and hind-dune regions of three localities (Someshwara, Thannir Bavi and Kaup) during June 12-20, 2013. The range of rainfall, humidity, air temperature, soil temperature and organic carbon during the survey period was $24.5-145.8 \mathrm{~mm} /$ day, $85-99 \%, 22.4-29.3^{\circ} \mathrm{C}, 25.5-30.1^{\circ} \mathrm{C}$ and $0.7-1.6 \%$, respectively. In three transects $(25 \times 25 \mathrm{~m})$ at a distance of $500 \mathrm{~m}$ on each location, the fruit bodies of macrofungi were scored. They were identified based on the standard descriptions (e.g., Pegler 1990, Jordan 2004, Phillips 2006, Cannon \& Kirk 2007, Mohanan 2011) and preserved in the mycological herbarium of the Department of Biosciences, Mangalore University (MUBSSDGKRSMF \# 1-38).

\section{Results}

\section{Species composition}

Table 2 provides the list of macrofungi recorded and the average number of fruit bodies in an area of $625 \mathrm{~m}^{2}(\mathrm{n}=9)$. Out of 38 macrofungi, 23 were identified to the species level, 14 were identified to genus and one was an unidentified agaric species. Macrofungi in the present study were represented by a wide range of species from perennial forms (e.g., Ganoderma lucidum) to delicate (e.g. Marasmius spp.) forms. Based on the present study and traditional knowledge of the coastal dwellers, ten fungi were considered as edible (which includes one Amanita sp.), six fungi were ectomycorrhizal (associated with Acacia or Casuarina or native plants), two were medicinal and one had a decorative value. Macrofungi were recorded on various substrates such as sand, sandy soil, termite mounds, leaf litter, twigs, bark, wood stubs and live roots (see Table 2; Fig. 2). Based on the average number of fruit bodies $\left(\geq 5\right.$ per $\left.625 \mathrm{~m}^{2}\right), 10$ macrofungi were dominant on CSD. These were Amanita sp., Collybia dryophila var. extuberans, C. fusipes, Coprinus plicatilis, Dacryopinax spathularia, Lactarius sp., Lentinus squarrosulus, Marasmius kisangensis, Marasmius sp. 2 and Scleroderma citrinum. 
Table 2 Macrofungi on the CSD of south-western of India.

\begin{tabular}{|c|c|c|c|}
\hline Taxon & $\begin{array}{l}\text { Mean fruit } \\
\text { bodies/625 m² } \\
(\text { mean, } n=9)\end{array}$ & Substrate & $\begin{array}{l}\text { Disturbance } \\
\text { status*** }\end{array}$ \\
\hline \multicolumn{4}{|l|}{ Edible } \\
\hline $\begin{array}{l}\text { Dacryopinax spathularia (Schwein.) G.W. } \\
\text { Martin (Fig. } 2 \mathrm{~g} \text { ) }\end{array}$ & 11.8 & Wood stub & $\mathrm{LD}, \mathrm{SD}$ \\
\hline Amanita sp.* & 7.2 & Sandy soil with roots & $\mathrm{LD}, \mathrm{MD}$ \\
\hline Lentinus squarrosulusMont. (Fig. 2h) & 5.2 & Wood stub & LD \\
\hline $\begin{array}{l}\text { Lycoperdon decipiens Durieu \& Mont. } \\
\text { (Fig. } 2 \mathrm{k} \text { )** }\end{array}$ & 4.4 & Sand & $\mathrm{LD}, \mathrm{MD}$ \\
\hline Termitomyces schimperi (Pat.) R. Heim & 2.0 & Termite mound & $\mathrm{SD}$ \\
\hline \multicolumn{4}{|l|}{ D.A. Reid (Fig. 2q) } \\
\hline Lycoperdon utriforme Bull. (Fig. 21) & 1.4 & Sandy soil & LD \\
\hline $\begin{array}{l}\text { Macrolepiota rachodes (Vittad.) Singer } \\
\text { (Fig. } 2 \mathrm{~m} \text { ) }\end{array}$ & 0.8 & Sandy soil & $\mathrm{SD}$ \\
\hline Pleurotus flabellatus Sacc. (Fig. 2p) & 0.4 & Bark & MD \\
\hline Lycoperdon sp.* & 0.2 & Sandy soil with roots & SD \\
\hline \multicolumn{4}{|l|}{ Ectomycorrhizal } \\
\hline Collybia fusipes (Bull.) Quél. (Fig. 2c) & 6.8 & Sandy soil with roots & MD \\
\hline Scleroderma citrinum Pers. & 5.0 & Sandy soil with roots & $\mathrm{LD}, \mathrm{MD}$ \\
\hline Pisolithus sp. & 1.6 & Sandy soil with roots & LD \\
\hline $\begin{array}{l}\text { Pisolithus albus (Cooke \& Massee) Priest } \\
\text { Medicinal }\end{array}$ & 1.0 & Sandy soil with roots & MD \\
\hline $\begin{array}{l}\text { Collybia dryophila var. extuberans (Fr.) P. } \\
\text { Roux (Fig. 2a, b) }\end{array}$ & 7.6 & Sandy soil & MD \\
\hline $\begin{array}{l}\text { Ganoderma lucidum (Curtis) P. Karst. } \\
\text { Decorative }\end{array}$ & 0.4 & Wood stub & MD \\
\hline $\begin{array}{l}\text { Microporus xanthopus (Fr.) Kuntze } \\
\text { Miscellaneous }\end{array}$ & 0.6 & Twig & MD \\
\hline Marasmius kisangensis Singer (Fig. 2n) & 7.0 & Leaf litter & SD \\
\hline Marasmius sp. 2 & 5.4 & Sandy soil & MD \\
\hline Coprinusplicatilis (Curtis) Fr. (Fig. 2d, e) & 5.2 & Sand & MD \\
\hline Lactarius sp. & 5.0 & Sandy soil & SD \\
\hline Crepidotus reversus (Berk. \& Broome) Sacc. & 4.0 & Twig & SD \\
\hline Marasmius sp. 1 & 3.4 & Sandy soil & LD \\
\hline $\begin{array}{l}\text { Unidentified (agaric sp. with yellow pileus } \\
\text { and stipe) }\end{array}$ & 3.0 & Sandy soil & LD, SD \\
\hline Macrolepiota sp. & 2.8 & Sandy soil & MD \\
\hline Crepidotus uber (Berk. \& M.A. Curtis) Sacc. & 2.6 & Twig & $\mathrm{LD}$ \\
\hline $\begin{array}{l}\text { Lepiota clypeolaria (Bull.) P. Kumm. } \\
\text { (Fig. } 2 \mathrm{i} \text { ) }\end{array}$ & 2.4 & Sand & MD \\
\hline $\begin{array}{l}\text { Marasmius spegazzinii (Kuntze) Sacc. \& P. } \\
\text { Syd. (Fig. 2o) }\end{array}$ & 2.2 & Leaf litter & MD \\
\hline Crepidotus sp. & 2.0 & Twig & MD \\
\hline Agaricus sp. 2 & 1.6 & Sandy soil & MD \\
\hline Daedalea sp. & 1.4 & Wood stub & SD \\
\hline Lenzites sp. & 1.4 & Wood stub & LD \\
\hline Lepiota sp. (Fig. 2j) & 0.8 & Sandy soil & $\mathrm{MD}$ \\
\hline Agaricus sp. 1 & 0.6 & Sandy soil & MD \\
\hline Cystolepiota $\mathrm{sp}$ & 0.6 & Sandy soil & MD \\
\hline Lentinus patulusLév & 0.4 & Bark & SD \\
\hline Agaricus caribaeus Pegler & 0.2 & Sandy soil & LD \\
\hline $\begin{array}{l}\text { Cystoagaricus trisulphuratus (Berk.) Singer } \\
\text { (Fig. 2f) }\end{array}$ & 0.2 & Sandy soil & LD \\
\hline
\end{tabular}

*species that is also ectomycorrhizal

**vulnerable or extinct in Britain (Evans et al. 2006)

***LD, less disturbance; MD, moderate disturbance; SD, severe disturbance 

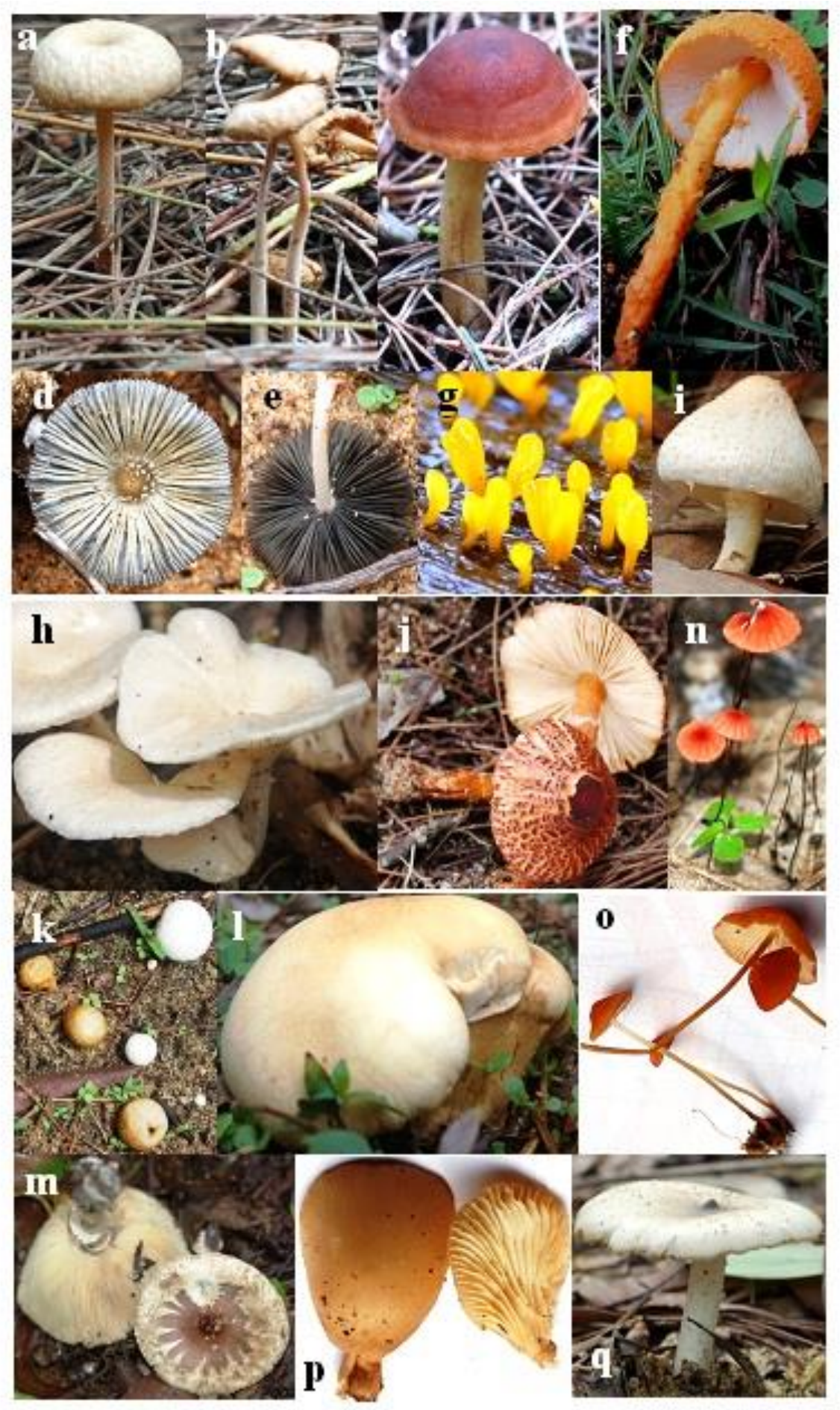

Fig. 2 -Representative macrofungi occurring on the coastal sand dunes of south-western India: a, b, Collybia dryophila var. extuberans on sandy soil amidst needles of Casuarina; c, C. fusipes on sandy soil amidst needles of Casuarina; d, Coprinus plicatilis on sandy soil (pileus top); e, $C$. plicatilis (gills); f, Cystoagaricus trisulphuratus on sandy soil with grass bed; g, Dacryopinax spathularia on dead Casuarina stub; h, Lentinus squarrosulus on dead Casuarina stub; i, Lepiota clypeolaria on sandy soil with Acacia litter; j, Lepiota sp. on sandy soil amidst needles of Casuarina; k, Lycoperdon decipiens on sandy soil; 1, L. utriforme on sandy soil with Acacia litter; m, Macrolepiota rachodes on sandy soil; n, Marasmius kisangensis on Acacia phyllode litter; o, M. spegazzinii on Acacia phyllode litter; p, Pleurotus flabellatus on Acacia bark, and q, Termitomyces umkowaan on termite mound. 


\section{Distribution}

The specific pattern of macrofungal distribution on CSD in disturbed regimes has been presented in a venn diagram (Fig. 3). Moderately disturbed dunes represented by the highest number of macrofungi (20 species), followed by less disturbed (14 species) and severely disturbed (11 species) dunes. Exclusive macrofungi were also higher in moderately disturbed dunes (16 species), compared to the dunes with less and severe disturbance (8 species each). Termitomyces umkowaan was the only fungus recorded in CSD with less, moderate and severe disturbances, whereas Crepidotus reversus, Daedalea sp., Lactarius sp., Lentinus patulus, Lycoperdon sp., Macrolepiota rachodes, Marasmius kisangensis and Termitomyces schimperi were confined to only the severely disturbed dunes (Table 2).

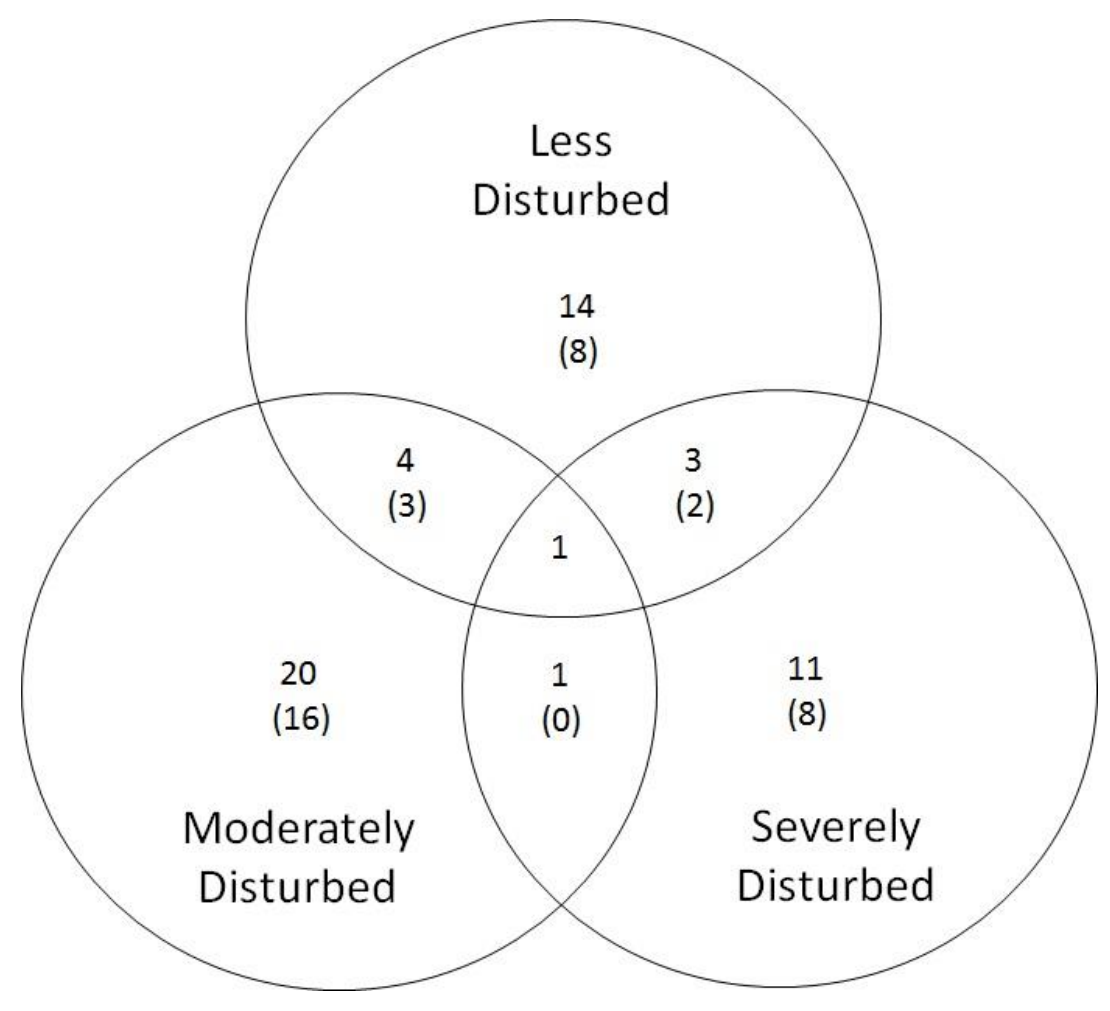

Fig. 3 -Venn diagram showing the pattern of distribution and richness of macrofungi on the coastal sand dunes with different disturbance regimes (less, moderate and severe) in south-western India (number of exclusive species in parenthesis).

\section{Discussion}

It is notable that several edible fungi occur on the CSD, and those are eaten by the coastal dwellers based on their traditional knowledge. The Amanita sp. (called 'motte anabe' in the vernacular name, Kannada, means 'egg mushroom') will be eaten in basidiocarp stage (egg or bulbous shape) or just erect out from basidiocarp (dumbbell shape: bulbous cap and bulbous base). It is interesting to note the occurrence of two termitomycetes (Termitomyces schimperi and T. umkowaan) on the CSD. Individual fruit bodies of termitomycetes found were big and constitute considerable weight and quantity for edible purposes. The occurrence of termitomycetes indicates the activities of termites or the presence of termite mounds underneath the CSD. According to Evans et al. (2006), Lycoperdon decipiens found in our study is vulnerable or extinct in Britain. Organic matter, especially the leaf litter or woody debris (authchthonous or allochthonous or both) on the CSD seems to constitute an important source of nutrition for macrofungal perpetuation. Human interference such as harvesting the vegetation and dismantling the dunes reduces the surface area as well as the accumulation of organic matter. Similarly, construction of seawalls by granite boulders prevents the deposition of allochthonous organic debris on the dunes from the sea. Natural and anthropogenic disturbances on the CSD should be at moderate level to maintain the 
biodiversity on the dunes at its peak (Connell 1978). Diversity of macrofungi on CSD seems to conform to Connell's hypothesis as evident in the numbers of arbuscular mycorrhizal fungi of the CSD (Beena et al. 2000).

The present survey revealed a wide variety of economically viable macrofungi on the CSD of south-western India despite their threatened status. Similar to the flora and fauna, macrofungi serve as a major decomposer component of CSD ecosystems (edible, ectomycorrhizal and medicinal) and it is warranted to develop their baseline data by temporal and spatial scales in different parts of the world. Removal of natural vegetation and 'grow and harvest' policy of exotic vegetation on the CSD have severe impact on the macrofungal distribution, richness and diversity. Several questions remain to be answered on the macrofungal community on CSD. These include (a) To what extent do the exotic plant species on the dunes support macrofungi? (b) Do they serve as indicators of status of CSD disturbance? (c) Are the macrofungi on CSD salt-tolerant? and (d) Are there any vulnerable or threatened or red-listed taxa in CSD?

\section{Acknowledgements}

Authors are grateful to Mangalore University for permission to carry out this study in the Department of Biosciences. One of us (SDG) acknowledges the award of an Inspire Fellowship by the Department of Science and Technology, New Delhi, Government of India (DST/INSPIRE Fellowship/2013/132: Award No. IF130237). We are thankful to Prof. K.S. Jayappa, Department of Marine Geology for lending the snaps of remnant coastal sand dunes, and Dr. Suryaprakash Shenoy and Mr. Keshavachandra, Department of Applied Botany, for confirmation of coastal sand dune vegetation.

\section{References}

Akata I, Yaprak AE. 2013 - A new Peziza record for Turkish mycobiota. Biological Diversity and Conservation 6, 32-34.

Ashkannejhad S, Horton TR. 2005 - Ectomycorrhizal ecology under primary succession on coastal sand dunes: Interactions involving Pinus contorta, suilloid fungi and deer. New Phytologist $169,345-354$.

Banerjee LK, Rao TA, Sastry ARK, Ghosh D. 2002 - Diversity of Coastal Plant Communities in India. Ministry of Environment and Forests, Botanical Survey of India, Kolkata, India.

Beena KR, Raviraja NS, Arun AB, Sridhar KR. 2000 - Diversity of arbuscular mycorrhizal fungi on the coastal sand dunes of the west coast of India. Current Science 79, 1459-1466.

Brundrett M. 1991 - Mycorrhizas in natural ecosystems. In: Begon M, Fitter AH, Macfadyen A (Ed.), Advances in Ecological Research, Volume 21, Academic Press Limited, London, 171-313.

Cannon PF, Kirk PM. 2007 - Fungal Families of the World. CAB International, United Kingdom.

Clark JR. 1996 - Coastal Zone Management Handbook. Lewis Publications, Florida.

Connell JH. 1978 - Diversity in tropical rain forests and coral reefs. Science 199, 1302-1310.

ECCF. 2001 - Datasheets of threatened mushrooms of Europe, candidates for listing in Appendix I of the convention. In: Convention on the Conservation on the European Wildlife and Natural Habitats, The European Council for Conservation of Fungi, France.

EEA Technical Report. 2001-2006 - Article 17, European Environment Agency, Brussels, Belgium: http://biodiversity.eionet.europa.eu/article17 (accessed on September 22, 2013).

Evans S, Henrici A, Ing B. 2006 - Red data list of threatened British fungi:http://www.britmycolsoc.org.uk/mycology/conservation/red-data-list/ (accessed on September 22, 2013).

Høiland K. 2012 - An investigation of basidiospore characteristics in sand dune mushrooms from Lista, South-Western Norway. Agarica 32, 49-58. 
Hoshino T, Takehashi S, Fujiwara M. 2009 - Typha maritima, a new species of Typhula collected from coastal dunes in Hokkaido, Northern Japan. Mycoscience 50, 430-437.

Jordan, M. 2004 - The Encyclopedia of Fungi of Britain and Europe. Francis Lincoln Publishers Ltd., London.

Malavasi M, Santoro R, Cutini M, Acosta ATR, Carranz ML. 2013. - What has happened to coastal dunes in the last half century? A multitemporal coastal landscape analysis in Central Italy. Landscape and Urban Planning 119, 54-63.

Maun MA 2009 - The Biology of Coastal Sand Dunes. Oxford University Press, United States of America.

McLachlan A, Brown AC. 2006 - The Ecology of Sandy Shores. Academic Press, Massachusetts.

Mohanan C. 2011. - Macrofungi of Kerala. Kerala Forest Research Institute, Hand Book \# 27, Kerala, India.

O'Hanlon R, Harrington TJ. 2011 - Diversity and distribution of mushroom-forming fungi (Agaricomycetes) in Ireland. Biology and Environment: Proceedings of the Royal Irish Academy 111B, 1-17.

Pegler D. 1990 - Kingfisher Field Guide to the Mushrooms and Toadstools of Britain and Europe. Kingfisher Publications, London.

Phillips R. 2006 - Mushrooms. Pan Macmillan, London.

Prasannarai K, Sridhar KR. 2001 - Diversity and abundance of higher marine fungi on woody substrates along the west coast of India. Current Science 81, 304-311.

Rodrigues RS, Mascarenhas A, Jagtap GT. 2011 - An evaluation of flora from coastal sand dunes of India: Rationale for conservation and management. Ocean \& Coastal Management 54, $181-188$.

Sá MCA, Baseia IG, Wartchow F. 2013 - Lactifluus dunensis, a new species from Rio Grande do Norte, Brazil. Mycosphere 4, 261-265.

Schlacher TA, Dugan J, Schoeman DS, Lastra M, Jones A, Scapini F, McLachlan A, Defeo O. 2007 - Sandy beaches at the brink. Diversity and Distributions 13, 556-560.

Seena S, Sridhar KR. 2004 - Endophytic fungal diversity of 2 sand dune wild legumes from the southwest coast of India. Canadian Journal of Microbiology 50, 1015-1021.

Sridhar KR. 2009 - Bioresources of coastal sand dunes - are they neglected? In: Jayappa KS, Narayana AC (Ed.), Coastal Environments: Problems and Perspectives, IK International Publishing House, New Delhi, 53-76.

Sulzbacher MA, Giachini AJ, Grebenc T, Silva BDB, Gurgel FE, Loiola MIB, Neves MA, Baseia IG 2013 - A survey of an ectotrophic sand dune forest in the northeast Brazil. Mycosphere 4, 1106-1116.

Taiga K, Tamotsu H, Seiji T, Akitomo U. 2011 - New records of two maritime Basidiomycetes, Tulstoma striatum and Geastrum quadrifidum in coastal dune of Eastern Hokkaido. Shiretoko Museum 32, 19-24.

Takehashi S, Kasuya T, Kakishima M. 2007 -Marasmiellus mesosporus, a Marasmius-blight fungus newly recorded from sand dunes of the Japanese coast. Mycoscience 48, 407-410.

Takehashi S, Kasuya T, Takehashi C. 2012 - Agaric fungi from Ishikari sand dunes in Hakkaido, Northern Japan. Wind Museum Bulletin of Ishikari Dune 2, 23-31.

Tedersoo L, Suvi T, Beaver K, Kõljalg U. 2007 - Ectomycorrhizal fungi of the Seychelles: Diversity patterns and host shifts from the native Vateriopsis seychellarum (Dipterocarpaceae) and Intsia bijuga (Caesalpiniaceae) to the introduced Eucalyptus robusta (Myrtaceae), but not Pinus caribea (Pinaceae). New Phytologist 175, 321-333.

Vila J, Àngel F, Llimona X. 1999 - Volvariella nigrovolvacea Kosina var. dunensis Vila, Àngel et Llimona var. nov. Revista Catalana de Micologia 22, 131-134.

Wolfe BE, Richard F, Cross HB, Pringle A. 2010 - Distribution and abundance of the introduced ectomycorrhizal fungus Amanita phalloides in North America. New Phytologist 185, 803816. 